This item was submitted to Loughborough's Research Repository by the author.

Items in Figshare are protected by copyright, with all rights reserved, unless otherwise indicated.

\title{
The behaviour of metal contaminants in silty sand and gravel
}

\author{
PLEASE CITE THE PUBLISHED VERSION \\ http://iieng.org/images/proceedings_pdf/3938E0915015.pdf \\ PUBLISHER \\ (c) International Institute of Engineers (IIENG) \\ VERSION \\ VoR (Version of Record) \\ PUBLISHER STATEMENT
}

This work is made available according to the conditions of the Creative Commons Attribution-NonCommercialNoDerivatives 4.0 International (CC BY-NC-ND 4.0) licence. Full details of this licence are available at: https://creativecommons.org/licenses/by-nc-nd/4.0/

\section{LICENCE}

CC BY-NC-ND 4.0

\section{REPOSITORY RECORD}

Abdulfatah, Ado Y., Ashraf El-Hamalawi, Andrew D. Wheatley, and A. Marto. 2019. "The Behaviour of Metal Contaminants in Silty Sand and Gravel”. figshare. https://hdl.handle.net/2134/32935. 


\title{
The Behaviour of Metal Contaminants in Silty Sand and Gravel
}

\author{
Dr. A.Y. Abdulfatah ${ }^{1}$, Dr. A. El-Hamalawi ${ }^{2}$, Prof. A.D. Wheatley ${ }^{3}$ and Prof. A. Marto ${ }^{4}$
}

\begin{abstract}
An investigative study is reported to determine the behaviour of metal contaminants in silty sand and gravel. A soil box experiment was conducted with a silty sand of permeability, $\mathrm{k}=$ $3.9242 \times 10^{-5} \mathrm{~m} / \mathrm{s}$. The sand was placed on a bedding of $6 \mathrm{~mm}$ peagravel, inside the test box. Copper Nitrate, Chromium Nitrate, Nickel Sulphate and Lead Nitrate were dissolved, mixed with RO (reverse osmosis) water for use in four separate experiments. Column tests were conducted with the same silty sand and gravel and under similar experimental conditions. Copper flushing was very slow, it was strongly absorbed to the silty sand and gravel. Chromium was entirely retained $(34 \mathrm{mg} / \mathrm{Kg})$ within the experimental system, and its released concentrations were very low. Nickel was shown to have a good aqueous solubility thus it was freely mobile in the sand. There was some minor adsorption of Nickel though lower than that of Copper and Chromium.
\end{abstract}

Keywords-Contamination, Heavy metals, Transport in soil, Adsorption

\section{INTRODUCTION}

OIL and sediments are the usual final destiny of all heavy

N

metals and other contaminants used by industry. Therefore soil infiltration and the ground water play an important role in transporting heavy metals in the natural environment. Some metals are essential nutrients to plants and animals at trace levels (Sparks, 2003). Many have no benefits and are accumulative toxins, (e.g. Cadmium and Lead). Exposure to elevated concentrations of heavy and transition metals is always undesirable to both plants and animals and ultimately also hazardous to human health (USEPA, 2001) via the food chain.. Metals such as Copper, Zinc, Chromium, Nickel and Lead are categorised as among the most common environmental pollutants in soil and water (Ozaki et al. 2004, Dang et al. 2002 \& Purohit et al. 2001). Unfortunately, the knowledge on how these metals bind to soils and the ease of removing them is very limited (Banat et al. 2005). This paper focuses on the behaviour of Copper, Chromium, Nickel and

Dr. Ado Yusuf Abdulfatah ${ }^{1}$ is with the Dept. of Civil Engineering, Bayero University Kano Nigeria, PMB 3011 Kano Nigeria.

Dr. Ashraf El-Hamalawi ${ }^{2}$ and Prof. Andrew D. Wheatley ${ }^{3}$ are with the Dept. of Civil \& Building Engineering, Loughborough University, UK.

Prof. Aminaton BT. Marto ${ }^{4}$ is with the Faculty of Civil Engineering, University Technology, Malaysia.
Lead in Silt, Sand and Gravel, the most common bedding materials used in buried infrastructure such as water pipes.

\section{A. Discharge of heavy metals in soil}

Discharges of heavy metals arise from a number of different sources. These sources include natural but also urban activities including transport, waste processing spills and infrastructure. Beasley et al. 2001, Lukar et al. 1997 and Coduto 1999 reviewed metal sources and grouped them into (1) Leakages and spills from industrial and agricultural activities (2) Mining and mineral extractions (3) Motor vehicles; including the action of corrosion and abrasion of vehicles and highway surfaces (4) Maintenance operations carried out on roads e.g., de-icing and road marking, and (5) Buildings in urban residential and industrial areas. Heavy metals constitute a significant fraction of the environmental risk from pollutants because they are in such common use as structural materials in the Built Environment. The concentration at which heavy metals exist in soil depends on their phase and mobility factors. These factors include biological transport, redox and adsorption/desorption reactions, physical transport processes and the nature of the receptive soils (Banat et al. 2005 \& Dang et al. 2002). The availability of heavy metals at deeper soil depths depends on factors such as: (1) the initial concentrations of the metals and their primary sources, (2) the mode of their transport, and (3) the characteristics of the receptive soils including flooding and groundwater level.

\section{B. Transport of metals in soil}

The literature reports on the existence and concentrations of heavy metals at different soil depths. Contaminant metals are reported at depths up to $4.0 \mathrm{~m}$ in some cases (e.g. Sprenke et al., 2000 \& Weng et al., 2000). Their movement in soil is via complex chemical and biological interactions: (Sharma et al. 2004). (Sparks, 2003 \& Denaix et al. 2001). Solubility is fundamental by an electrochemical reaction resulting in liberation of cations as electrolytes, Marcus (2002). . Simple ion exchange and solubilisation interactions take place relatively quickly but true chemical reactions such as the formation of metallic salts and re-precipitation as crystals will be dependent on soil conditions and may take several months to develop. They will never reach equilibrium in a reasonable 
time. The equations governing water movement in soil are the basis of understanding transport of heavy metals in the soil. . The rate of water flows in soils is quite well understood but the kinetics and reactions depending on the magnitude of forces and gradients with soil is less well understood (Yong et al. 1992). Water transport in soil is itself complex and influenced by saturated and partially saturated soils. Thus the transport of heavy metals in soil is expected to be influenced by (1) hydraulic gradient (Darcy's law), (2) concentration gradient (Fick's law), and (3) other soil, metal reactions. Both the dissolved and particle fractions of heavy metals are involved in the transport processes (Denaix et al. 2001). Therefore it is difficult to predict heavy metals' movement in soil using these basic equations. The movement of solutes in unsaturated soil has been described as one of the complex and critical processes in hydrology (Dou et al. 1999). This paper presents experimental data on the movement of common urban metals in a well controlled soil environment that is typically used to surround buried water pipes.

\section{EXPERIMENTAL MODEL}

A soil box experiment was conducted with a silt sand of permeability, $\mathrm{k}=3.9242 \times 10^{-5} \mathrm{~m} / \mathrm{s}$ ISO standard. The sand was placed on a bedding of $6 \mathrm{~mm}$ pea-gravel, inside the test box. The gravel served the function of facilitating drainage and preventing clogging of the sampling tube by fine sand particles (Etchebers et al. 2007). Copper Nitrate, Chromium Nitrate, Nickel Sulphate and Lead Nitrate were dissolved, mixed with RO (reverse osmosis) water and sprayed on xmm of topsoil in four separate experiments. The most soluble metal salts were used for good solubility. The concentrations of metals used were based on the average values obtained from literature (Carrington et al. 1998). These concentrations were 26.0 $\mathrm{mg} / \mathrm{Kg}$ for Copper $(\mathrm{Cu}), 84.0 \mathrm{mg} / \mathrm{Kg}$ for Chromium $(\mathrm{Cr}), 34.0$ $\mathrm{mg} / \mathrm{Kg}$ for Nickel (Ni) and $29.0 \mathrm{mg} / \mathrm{Kg}$ for Lead. The metal solutions were sprayed on the topsoil and a maturation period of one week was allowed for metal equilibrium in the sand to occur before water irrigation representing rainfall was commenced. A flow rate of $0.5 \mathrm{litre} / \mathrm{min}$ was set, giving a rainfall velocity of $0.8681 \times 10^{-5} \mathrm{~m} / \mathrm{s}$ through a 24 point purpose-made irrigation system on the top soil. Column tests were conducted with the same silt, sand and gravel and under similar experimental conditions. This was done in order to measure scale up effects on leaching between the two experimental setups.

Irrigation was conducted for four hours per day (11 am to 3 $\mathrm{pm})$. In all the cases, the irrigated tap water was integrated into a single bulk volumes from which two sub-samples were taken from 90 litres at $4 \mathrm{pm}$ and finally from 120 litres at 10 am the following morning. Samples of $600 \mathrm{ml}$ were collected in test bottles (Mary, 2005). This was done for a period of fifteen days for each of the four separate metal experiments. Sample collection was via a small drain at the bottom of the test box. The sample collection at $4 \mathrm{pm}$ was at a time when water drainage from the sand was still in progress. Whereas, the collection of samples at 10 am was designed to represent all of the drained water.

\section{EXPERIMENTAL RESULTS}

The collected samples were immediately tested for temperature, $\mathrm{pH}$, conductivity and total dissolved salts TDS before storage in a cold room for metal analysis at a later time. An Inductively Coupled Plasma (ICP) machine was used to analyse the concentrations of the metals.

\section{A. Soluble Copper Concentration}

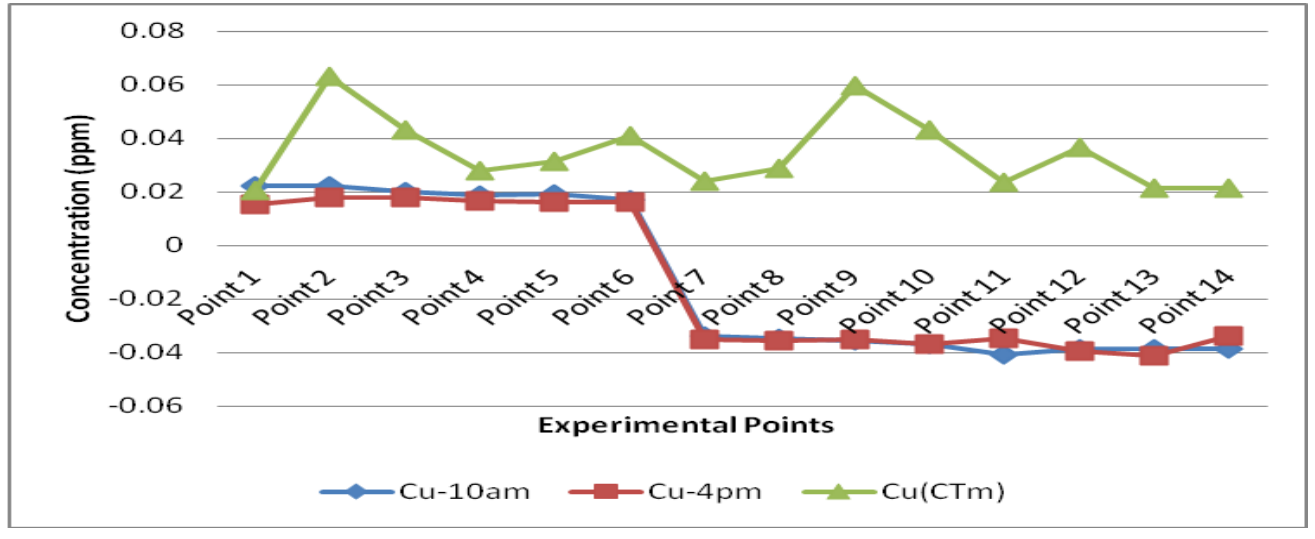

Fig 1. Soluble Copper content from $\mathrm{Cu}\left(\mathrm{NO}_{3}\right)_{2}$ experiment

Fig 1 shows soluble Copper concentrations in the two daily leachates and the column samples respectively. The detection level of the ICP machine was 0.002 ppm for Copper and its average in tap water content was $0.05 \mathrm{ppm}$. It can be seen from this figure that Copper concentrations were at their highest $(0.0223 \mathrm{ppm})$ in the first daily samples and thereafter for the 
next six days The two samples gave similar results (days 3 to 6) with values ranging from 0.017 to $0.018 \mathrm{ppm}$.

The copper concentrations in the leachate then went below the detection level of the ICP machine (which was $0.002 \mathrm{ppm}$ ) from day 7 through to the end of the experiment. There is similar behaviour for Copper in both the first and second daily samples although not in the column study. One suggestion from this pattern is that soluble copper concentrations could be linked to the organic carbon in the drainage. This was based on results from McBride et al. (1997) \& Sauvé et al. (1998) who both reported that soluble Copper was related to both the total Copper and the organic matter content in soil. Copper is thought to bind to soil particles dependant on the organic matter content of the soil. The soil particles absorb most of the Copper but soluble organic carbon also chelates and mobilises some copper. Organic carbon was highest at the start of the experiment (36.00 ppm) and later dipped to the background level in tap water of $3.00 \mathrm{ppm}$. The experimental sand was silty sand, with a smaller soil fraction of about $10 \%$ with a surface area of $12.941 \mathrm{~m}^{2} / \mathrm{g}$. This could therefore influence the adsorption solubility of Copper in soils. Lu et al (2004) and Young, et al (1992).

There was also a slight increase in $\mathrm{pH}$ values in the leachate, from start to finish of the experiment (6.80 to 7.50). The decrease in Copper concentrations at the middle of the experiment coincided with the point where the $\mathrm{pH}$ started to increase and is an alternative explanation the organic matter creating the acidity because Copper dissolves preferentially in lower $\mathrm{pH}$ values (max soil $\mathrm{pH}$ about 5.5), Martinez et al. (2000) and Agbenin \& Oloja (2004).

Further evidence for these two theories was derived from the separate column experiments. In the column experiments acid-washed gravel was used prior to the known concentration of Copper experiment (fig 1). The copper release is much more uniform but analysis of the results demonstrated much less Copper than applied. There was also an increase in Iron content (above tap water level) not seen in the scaled up experiments. This implies that the gravel absorbs Copper and releases Iron. Gravel is composed of Calcium (Ca), Silica ( $\mathrm{Si}$ ), Aluminium ( $\mathrm{Al})$, Iron ( $\mathrm{Fe})$ and a little of the other elements (Vega et al., 2001). The adsorption of Copper by the gravel was found to follow the Freudlich isotherms with constants $\mathrm{n}=$ $0.625, \mathrm{k}=2.69$ and a regression coefficient, $\mathrm{R}^{2}=0.999987$ (Abdulfatah et al, 2014). Though the adsorption intensity was low with a value of $n$ less than 1 , the gravel was found to have a very good adsorption capacity (k>2), Apark et al. (1998). The results of sand/gravel column test show that the column produced Copper concentrations higher than the main experiment. Abdulfatah et al, (2009) confirmed high concentrations of Copper from column test. The experiment failed to differentiate between acid or organic release since both the $\mathrm{pH}$ and organic matter were stable in the column tests column drainage always had neutral $\mathrm{pH}$.

\section{B. Soluble Chromium Concentration}

Fig 2 shows the soluble concentrations of Chromium in the two daily leachates and the column samples respectively. It can be seen in this figure that Chromium appeared in the first daily samples with a value of $0.06 \mathrm{ppm}$, as would be expected because of its dosing. Chromium concentrations then decreased gradually to $0.01 \mathrm{ppm}$ through the next 7 days of artifical rain. It then increased to a higher value of $0.022 \mathrm{ppm}$ and later fluctuated within a range of 0.007 to $0.022 \mathrm{ppm}$ (within the band of experimental error). Chromium was absent in nearly all the samples in the first copper experiment. This was because of its low value in tap water, its retention and minimal leaching potential from the materials used in the experiment. Unlike the first copper experiment the sand and gravel had now been flushed out of easily soluble organic matter.

The changes in the Chromium fluctuations could depend on factors such as, solubility of the Chrome ion in soil, amount of air entering the system in between irrigation flushes, and other changes in the environment. Both daily samples show a similar behaviour maximum $0.03 \mathrm{ppm}$ in the $4.00 \mathrm{p} . \mathrm{m}$. sample with falls towards the end of the experiment. The concentrations in the 4.00 p.m. daily samples were higher than those in the 10 a.m. daily samples later in the experiment. Interestingly, the results of the column experiment show negative values throughout the experiment. This further confirms the absence of Chromium in the tap water and the sand and gravel used in this experiment. There was no leaching of Chromium despite the greater column velocity compared to the test box. 


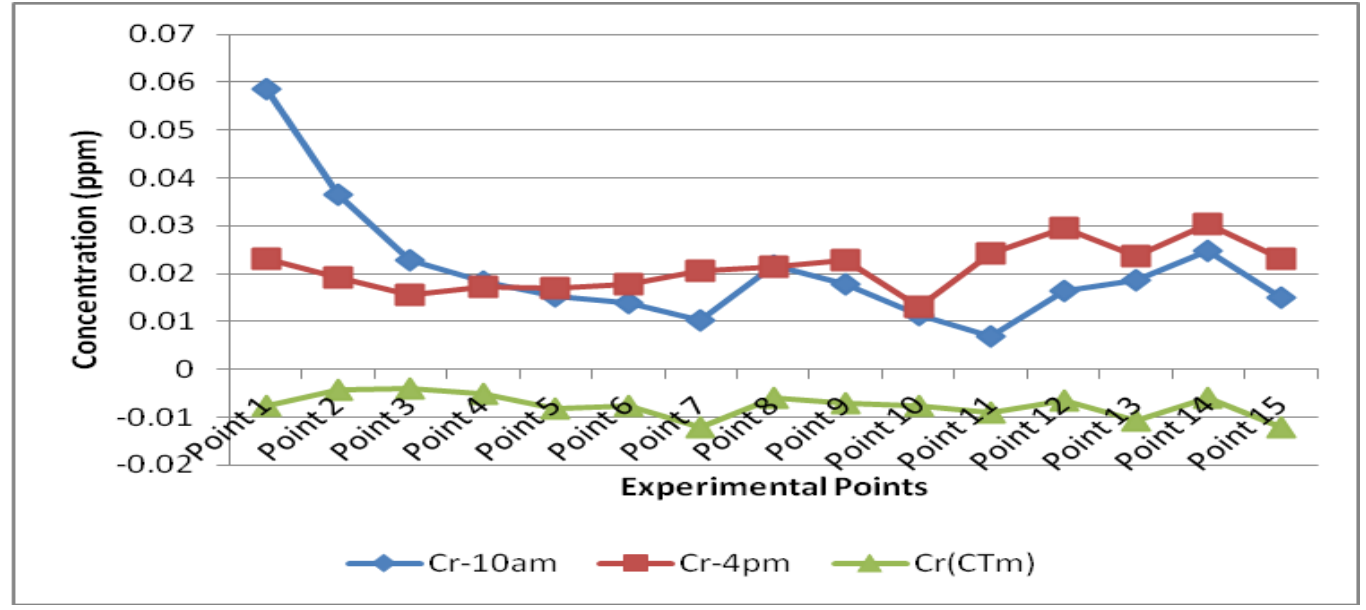

Fig. 2 Soluble Chromium content from $\mathrm{Cr}\left(\mathrm{NO}_{3}\right)_{3}$ experiment

\section{Soluble Nickel Concentration}

Fig 3 shows soluble Nickel concentrations in the two leachate samples and column samples. The tap water value for Nickel was measured in this study as $0.007 \mathrm{ppm}$ and its detection limit of the ICP machine was $0.005 \mathrm{ppm}$. The concentrations of Nickel in the first experiment (with $\left(\mathrm{CuNO}_{3}\right)_{2}$ dosing) ranged between 0.001 and $0.007 \mathrm{ppm}$, indicating the tap water as the only likely source. Nickel concentration was zero in the second experiment (with $\mathrm{Cr}\left(\mathrm{NO}_{3}\right)_{3}$ dosing). In this third experiment with Nickel dosing there is Nickel ions in the samples might be expected. Fig 3 shows a value of $0.007 \mathrm{ppm}$ in the first daily samples Followed by an immediately rise at the second irrigation, the (concentration of7.092 ppm), indicating no adsorption of the added Nickel.

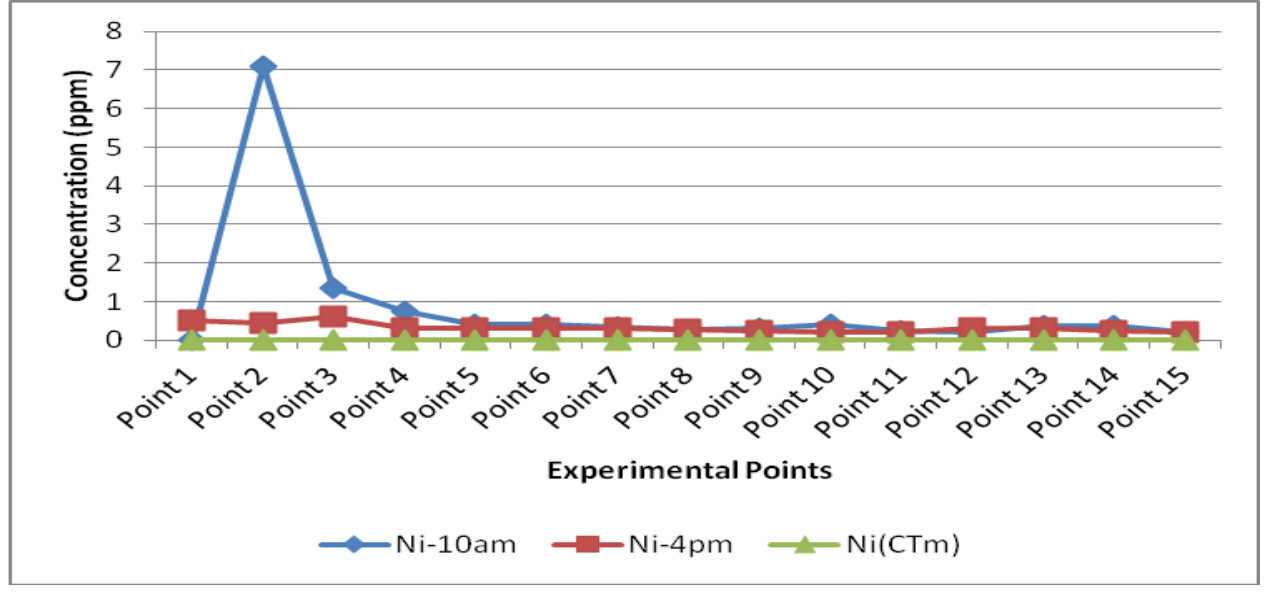

Fig 3 Soluble Nickel content from NiSO4 experiment

This shows that Nickel has a very good solubility and it was entirely mobile in the soil, sand and gravel. The amount of Nickel dosed on the topsoil (of mass $820.5 \mathrm{~kg}$ ) was 68.922 grams. The total hydraulic loading throughout the experiment was 1800 litres (120 litres times 15 days). Assuming there was no adsorption of Nickel by the sand and gravel, the expected total concentration of Nickel in solution would have been $38.29 \mathrm{ppm}$. A value of $7.092 \mathrm{ppm}$ from one irrigation of 120 litres representing 0.85 grms (total) was an indication of its solubility. Nickel dipped to a value of $1.352 \mathrm{ppm}$ and at the third irrigation gradually decreased to a value of 0.2183 ppm at the end of the experiment. This would be expected because of its free movement in the sand. The first daily (sample 4 p.m.) results show lower Nickel concentrations ranging from 0.2008 to $0.6273 \mathrm{ppm}$. The two sets of results merged in the rainfall from day 5 to the end of the experiment. The range in the column results without dosing was from 0.0085 to $0.0132 \mathrm{ppm}$, averaging to $0.0107 \mathrm{ppm}$. This confirms a very low value of Nickel in tap water and the materials used (sand and gravel).

\section{Soluble Lead Concentration}

Soluble concentrations of Lead in the two leachates and column samples are shown in figure 4 . It can be noticed that 
Lead did not appear in either of the daily samples despite its dosing in this experiment. This indicates Lead's good affinity for the soil particles coupled with its poor solubility in water. Linde (2007) reported on modelling movement in soil, and also found that Lead was strongly adsorbed by soil, far more than the predictions of their model. The detection limit of the ICP machine for Lead was $0.025 \mathrm{ppm}$ and its tap water content was measured as $0.002 \mathrm{ppm}$, which was lower than the ICP machine's sensitivity. The concentration was then regarded as zero. The column results showed some traces of Lead above the detection limit, which was an indication of potential leaching of Lead from the test sand, possibly as a result of high water velocity in the glass column.

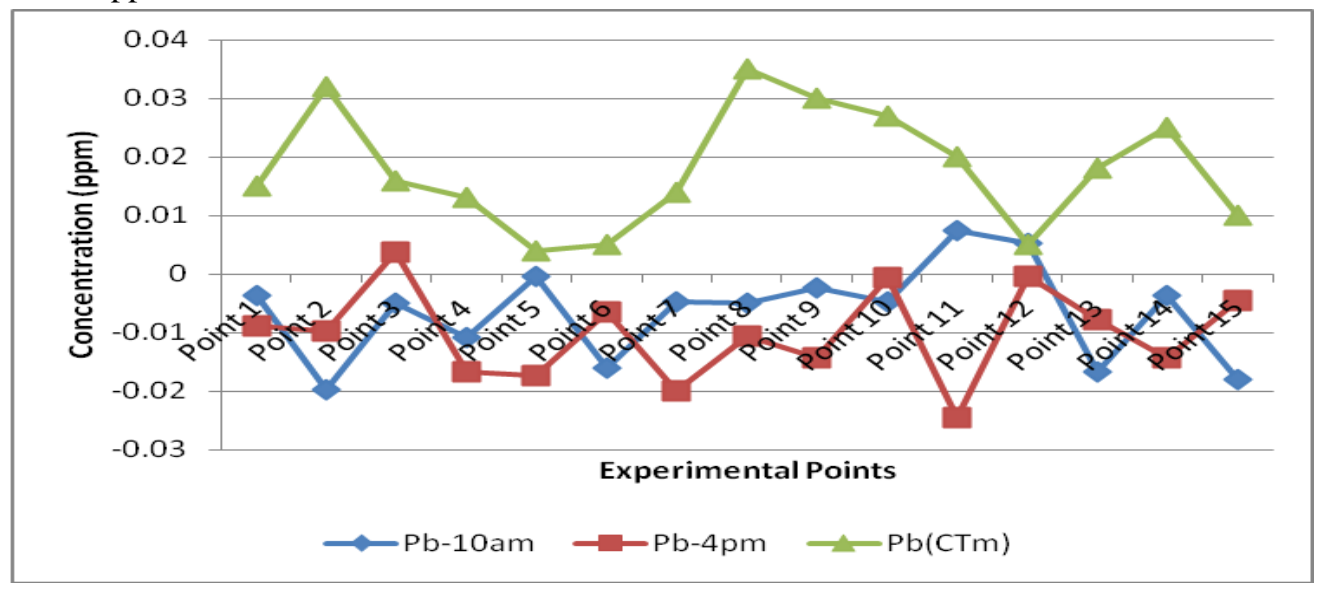

Fig 4 Soluble lead content from $\mathrm{Pb}\left(\mathrm{NO}_{3}\right)_{2}$ experiment

\section{CONCLUSION}

1. Copper flushing was very slow, it was strongly absorbed to the silt sand. The release was linked to organic matter and $\mathrm{pH}$ of the soil. Greater reproducibility and retention was shown by the pre-acid washed soils in the column experiment.

2. Similar behaviour although less complex was observed from the chromium. In this case chromium was not in the materials of the experiment. There was very little in tap water, as well as its fixed nature in the sand and gravel within the experimental conditions. Thus in general Chromium was entirely retained $(\sim 34 \mathrm{mg} / \mathrm{Kg})$ within the experimental system, and its released concentrations were very low.

3. Nickel was shown to have a good aqueous solubility thus it was freely mobile in the sand. There was some minor adsorption of Nickel (x mg/Kg), its adsorption was lower than that of Copper and Chromium.

4. There was a total retention of Lead by the sand, indicating Lead's good affinity for soil particles coupled with its poor aqueous solubility.

5. The scope of the study was three years equivalent rainfall which is low compared to other areas in the UK and world (with up to $5,000 \mathrm{~mm} /$ annum in the UK). A longer period with higher rainfall might also produce more leaching of the added metals but in general all the metals are retained quite well. Even in the case of Nickel, the least retained there was $\mathrm{x} \%$ recovered of the Nickel introduced demonstrating that the metals are likely to accumulate in soils and bedding around pipes.

\section{ACKNOWLEDGMENT}

The authors of this paper would like to acknowledge Bayero University Kano-Nigeria, Petroleum Technology Development Fund Nigeria and Loughborough University, UK for sponsoring this research and the presentation of this paper at this conference.

\section{REFERENCES}

[1] Abdulfatah, A.Y., El-Hamalawi, A. and Wheatley, A. D. (2009). Leaching of Trace Metals from Two Different Size Soils, Advanced Materials Research, Trans Tech Publications, Switzerland, Vol. 62-64, pp. 197-202.

[2] Abdulfatah, A.Y., Salihi, I.U. and Anwar, A.R. (2014). Adsorption of Copper by Two Different Size Gravels, Journal of Clean Energy Technologies. IACSIT Press, Singapore,Vol. 2, No. 3, pp. 229-232.

[3] Agbenin, J O \& Olojo, L A 2004, Competitive adsorption of copper and zinc by a Bt horizon of a savanna Alfisol as affected by $\mathrm{pH}$ and selective removal of hydrous oxides and organic matter, Geoderma, Vol. 119, pg. 85-95. http://dx.doi.org/10.1016/S0016-7061(03)00242-8

[4] Apak, R., Tutem, E., Hugal, M. and Hizal, J. (1998). Heavy Metal cation retention by unconventional sorbents. Water Research, 32, 430-440. http://dx.doi.org/10.1016/S0043-1354(97)00204-2

[5] Banat, KM, Howari, FM \& Al-Hamad, AA 2005, Heavy metals in urban soils of central Jordan: Should we worry about their environmental risk? Environmental Research, Vol. 97, pg. 258273.

http://dx.doi.org/10.1016/j.envres.2004.07.002 
[6] Beasley, G \& Kneale, P 2001, Macroinvertebrates, Heavy Metals and PAHs in Urban Watercourses, Working Paper 01/07, Department o Geography University of Leeds, UK.

[7] Carrington, E.G., Davis, R.D. and Pike E.B. (1998). "Review of the Scientific Evidence Relating to the Controls on the Agricultural Use of Sewage Sludge", Final report to the Department of the Environment, Transport and the Regions, Department of Health, Ministry of Agriculture, Fisheries and Food and the UK Water Industry Research Limited. Report No: DETR $4415 / 3$.

[8] Coduto, DP 1999, Geotechnical Engineering Principles and Practice, Prentice-Hall, Inc., New Jersey.

[9] Dang, Z, Liu, C \& Haigh, MJ 2002, Mobility of heavy metals associated with the natural weathering of coal mine spoils, Environmental Pollution, Vol. 118, pg. 419-426. http://dx.doi.org/10.1016/S0269-7491(01)00285-8

[10] Denaix, L, Semlali, RM \& Douay, F 2001, Dissolved and colloidal transport of $\mathrm{Cd}, \mathrm{Pb}$, and $\mathrm{Zn}$ in a silt loam soil affected by atmospheric industrial deposition, Environmental Pollution, Vol. 113, pg. 29-38. http://dx.doi.org/10.1016/S0269-7491(00)00204-9

[11] Dou, C, Woldt, W \& Bogardi, I 1999, Fuzzy rule-based approach to describe solute transport in the unsaturated zone, Journal of Hydrology, Vol. 220, pg. 74-85. http://dx.doi.org/10.1016/S0022-1694(99)00065-7

[12] Etchebers, O., Kedziorek, M. A. M. and Bourg, A. C. M. (2007). Soil Water Chemistry as an indicator of the Reproducibility of Artificially Contaminated Soil Mesocosms. Water Air and Soil Pollution, 179, p125-134. http://dx.doi.org/10.1007/s11270-006-9219-6

[13] Lu, N \& Licos, WJ 2004, Unsaturated soil mechanics, John Wiley \& Sons, Inc. New Jersey.

[14] Luker, M \& Montague, K 1997, Control of Pollution from Highway Drainage Discharges, A CIRIA Reprint, Westminster, London.

[15] Marcus, P 2002, Corrosion mechanisms in theory and practice, Second edition, Marcel Dekker, Inc. New York. http://dx.doi.org/10.1201/9780203909188

[16] Martinez, CE \& Motto, HL 2000, Solubility of lead, zinc and copper added to mineral soils, Environmental Pollution, Vol. 107, pg. $153-158$. http://dx.doi.org/10.1016/S0269-7491(99)00111-6

[17] Mary, A. H. F. (Managing Editor) (2005). Standards Methods for the Examination of Water and Waste Water, $21^{\mathrm{st}}$ Edition, APHA, Washington.

[18] McBride, M., Sauve, S. and Hendershot, W. (1997). Solubility control of $\mathrm{Cu}, \mathrm{Zn}, \mathrm{Cd}$ and $\mathrm{Pb}$ in contaminated soils. European Journal of Soil Science. 48, 337-346. http://dx.doi.org/10.1111/j.1365-2389.1997.tb00554.x

[19] Ozaki, H, Watanabe, I \& Kuno, K 2004, Investigation of the Heavy Metal Sources in Relation to Automobiles, Water, Air and Soil Pollution, Vol. 157, pg. 209-223. http://dx.doi.org/10.1023/B:WATE.0000038897.63818.f7

[20] Purohit, KK, Mukherjee, PK, Khanna, PP, Saini, NK \& Rathi, MS 2001, Heavy metal distribution and environmental status of Doon Valley soils, Outer Himalaya, India, Environmental Geology, Vol. 40, no. 6, pg. 716-724. http://dx.doi.org/10.1007/s002540000229

[21] Sauve, S., Hendershot, W. and Allen, H.E. (2000). Solid Solution partitioning of metals in contaminated soils: Dependence on $\mathrm{pH}$, total metal burden and organic matter, Environmental Science and Technology. 34, 1125-1131 http://dx.doi.org/10.1021/es9907764.

[22] Sparks, DL 2003, Environmental Soil Chemistry, Second edition, Elsevier Science, California.

[23] Sprenke, KF, Rember, WC, Bender, SF, Hoffmann, ML, Rabbi, F \& Chamberlain, VE 2000, Toxic metal contamination in the lateral lakes of the Coeur d'Alene River valley, Idaho, Environmental Geology, Vol. 39, No. 6, pg. 575-585.

http://dx.doi.org/10.1007/s002540050469
[24] USEPA 2001, Environmental Pollution and Disease, Retrieved: June 03, 2005, from http://www.epa.org/indicators/roe/html/roeHealthMe.html-37k.

[25] Weng, H \& Chen, X 2000, Impact of polluted canal water on adjacent soil and groundwater systems, Environmental Geology, Vol. 39, no. 8, pg. 945-950. http://dx.doi.org/10.1007/s002549900069

[26] Yong, NR, Mohamed, AMO \& Warkentin, BP 1992, Principles of Contaminant Transport in Soils, Elsevier Science Publishers B.V., the Netherlands. 